\title{
A Practice Study on the Informatization of Primary School Chinese Curriculum from the Perspective of Edutainment
}

\author{
Li Hongke ${ }^{1}$ \\ ${ }^{1}$ Department of Educational Technology, Faculty of Education of Hubei University, Wuhan, Hubei, China \\ Correspondence: Li Hongke, Department of Educational Technology, Faculty of Education of Hubei University, \\ Wuhan, Hubei, 430062, China. E-mail: Lhk315@126.com
}

Received: September 13, 2013

Accepted: November 27, 2013

Online Published: February 12, 2014

doi:10.5539/jel.v3n1p27

URL: http://dx.doi.org/10.5539/jel.v3n1p27

\begin{abstract}
This article is based on some of the results of the cooperative project "A Practice Study on Information-based Teaching" started and accomplished by Hubei University and other secondary and primary schools. This paper elaborates on the connotation of edutainment and explores ideas and design strategies of primary school Chinese curriculum from the perspective of edutainment. Enlightened by the idea of edutainment, this paper makes an in-depth analysis of and demonstrates the nature, grounds, and strategies of the informatization of primary Chinese curriculum to discuss the design and development of course materials in information-based teaching and new ideas of information-based teaching practice.
\end{abstract}

Keywords: informatizaiton of curriculum, edutainment, information-based teaching, teaching through lively activities

\section{The Connotation of Edutainment}

With accordance to human cognition and by means of information technology, edutainment is such a teaching method that combines technology and art, theory and practice, and makes the most of entertainment characteristics to achieve the maximum respect for the life of the learner's lives and cognition (Li, 2008). The fact that the concept of edutainment was put forward is no accident, but an inevitable outcome of the gradual process of its historical development and accumulation. During China's Spring and Autumn Period, the great educator Confucius proposed that education should formally put more emphasis on recreation. The famous American philosopher and educator John Dewey pointed out that education should respect the children's individuality, which stressed the concept of learning from practicing and being educated by life. As an expert of the new curriculum reform, Professor Ye Lan's quotation that "classrooms should be overflowing with vitality" has made an enormous impact on the education sector at home (Education Research, 1997, 9). Thus, edutainment is not new but an ideal state of education in constant pursuit by people of different ages. In traditional teaching, due to the less developed information technology, it was hardly possible to realize edutaiment. In an information-based teaching environment, in addition to mere texts and pictures, advanced digital technology can also integrate graphs, sound, animations, and videos into the presentation of teaching information, which can provide more technical support and condition protection for teaching through games and teaching through lively activities.

Edutainment does not simply mean amusing the students, nor teachers' self entertainment. It has a sound multi-disciplinary ground of pedagogy, psychology, and information technology. From a pedagogic point of view, edutainment is in line with the "student-oriented" educational philosophy of the new curriculum (Trial Implementation, 2001), which suggests that in teaching teachers should pay more respect and create an environment for the development of students' individuality. From the perspective of information technology, edutainment conforms to the essential characteristics of information technology applied to teaching practice and meets the essential requirements of the integration of technology and education, which makes education become an "art". From the perspective of psychology, edutainment satisfies students' psychological requirements of learning and follows students' cognitive rules so that learning becomes more relaxing and entertaining. 


\section{An Analysis of the Nature of the Informatization of Primary School Chinese Curriculum}

Primary school Chinese curriculum is a comprehensive practical curriculum featuring instrumental and humanities characteristics (Yang, 2008). Based on this, the nature of the informatization of primary school Chinese curriculum is to give full play to the strengths of information technology, which can facilitate teachers to convey the information-based course contents of electronic texts, graphs, images, sound, animations, videos and so on to students so as to enhance the students' Chinese literary attainment. For example, the lifelike and information-based videos can reproduce the real scenes, characters and events. They can evokes students' feelings and facilitate their understanding, as they meet the basic requirements of the elementary school students' perceptual knowledge and thus may help to stimulate and nurture students' interests in Chinese language. High-fidelity stereo can be added as background music to voice reading. Standard Mandarin and scene music can encourage students to enjoy the context, tone, and intonation of what they are listening to. With constant training of Chinese intuition, students will make great progress in enhancing their reading ability and oral communicative ability. Combined with color, light and actions, the color text, three-dimensional text, WordArt, and animated text are not only consistent with the writing norms of Chinese language but also endowed with a rich variety of font formats, which will promote students' language acquisition, like learning to read, reading and writing. With simulation, scenarios, games, and vivid, amusing animations can arouse students' interests in learning, develop their minds, and help them to find out their ways of learning Chinese so that they can finally form a good habit of language learning. Creatively designed graphs and images can show the details, set the scene, show or hide questions, and provide resources to prompt students to think and explore on their own initiatives. Multimedia which integrates a variety of elements can reveal the essence and meaning of Chinese language course and thus strengthen students' ability of language application, like writing and expressing emotions.

\section{Pedagogical Implications Based on Edutainment for the Informatization of Primary School Chinese Curriculum}

Under the guidance of the ideas and theories of modern education, the essence of edutainment is to make the best of the advantages of information technology to fulfill relaxing teaching and learning and to achieve the effect of teaching through lively activities. Similarly, under the guidance of the ideas and theories of modern education, the informatization of curriculum gives full play to the advantages of information technology to complete the instructional design, develop teaching resources, create teaching situations, and transform abstract teaching contents into visual and vivid symbolic forms to facilitate learners' understanding and perception. As can be seen from the concept of edutainment, edutainment and information-based teaching have internal consistencies: their guiding ideologies are the ideas and theories of modern education; their purpose is to improve teaching and learning outcomes; both their targets are students. Therefore, they are consistent in essence in that their methods are complementary and their processes can be mingled. In addition, multi-media can be employed to both of them. Edutainment is the significance and essence of information-based teaching and information-based teaching is an effective way to achieve edutainment. Thus, happy learning and learning in joy is the essence of both edutainment and information-based teaching. From the design, development, and application of resources to the emphasis on key points, the explanation of difficult points, and the expansion of teaching contents, the informatizaiton of curriculum will always have to take recreational ways into account and involve entertainments to realize relaxing teaching and happy learning to the fullest (Xie, 2005).

\section{Strategies of the Informatization of Primary School Chinese Curriculum from the Perspective of Edutainment}

The shared characteristic of primary school children is that they are too young to think rationally. Therefore, the abstract teaching materials and the "chalk and talk" teaching method can no longer meet the students' learning needs (Hao, 2006). The 2011 New Course Standards emphasizes that teaching should be student-oriented and that students should take their own initiatives to gain knowledge. It also highlights that greater efforts should be made to develop high-quality teaching resources and that students should be instructed to think independently and learn to work with others as a team. In the information-based teaching environment, information technology plays a significant and unique role. However, if information technology can not combine the new teaching ideas with edutainment strategies, it will hardly make any difference. Therefore, from the perspective of edutainment, it is necessary to upgrade the theoretical system of information-based teaching and to think about strategies contributing to the informatization of primary school Chinese curriculum. This satisfies the basic requirements of the new curriculum standards, and constitutes an effective strategy of it, and proposes an innovative approach to designing information-based teaching resources. 


\subsection{The Design and Production of the Lead-In of Courses}

The lead-in of courses focuses on establishing relationships between the course contents and stimulating students' interests in learning. The learning of new courses and the course contents already learnt by students are inextricably related, which means that when teachers are designing the lead-in, they are supposed to consider not only the knowledge and experience the students have gained, but also the connection between what they have mastered and the new course contents to realize a natural transition (Sun \& Xie, 2009). Nonetheless, this natural transition should not be merely an interlude. It should serve as a lead-in and thus pique students' interests in learning by associating their characteristics and learning needs. For instance, the writer advised the subject teacher to choose the song of the flash animation named Naughty Cats (2'5") as a lead-in for teaching the article entitled Cat to the fourth grade pupils. The background music sounds wonderful and students could see on the screen a lovely cat climb the TV set, and jump into the refrigerator. The lyrics of the song gave students a vivid description of the cat's loveliness and naughtiness, which agreed with the contents of this article, connected what students had learnt with what they were to learn, and aroused their interests in learning, thus amusing them and exerting strong influence on them.

\subsection{The Design and Production of the Course Content}

The design of the course contents should attach more importance to perceiving and understanding. The design should be fulfilled by analyzing knowledge points and adopting proper ways, like texts, graphs, images, sound, animations, or videos to present them. It is crucial to choose an appropriate information-based means to make the knowledge points perceived and understood more easily by students.

In fourth grade Chinese curriculum "cat" as an example. This is a real classroom, the teacher's teaching courseware is just the beginning of the text with a few pictures of the cat as a curriculum imported. The rest are text display, the whole process is basically stuck in the text teaching. Information technology teaching methods have not been fully applied, but can not reflect the advantages of information technology teaching. The author, after communicating with the language teacher, re-edit, and design the courseware. The example design basis is as follows.

Chart 1 . The first paragraph design of curriculum informatization

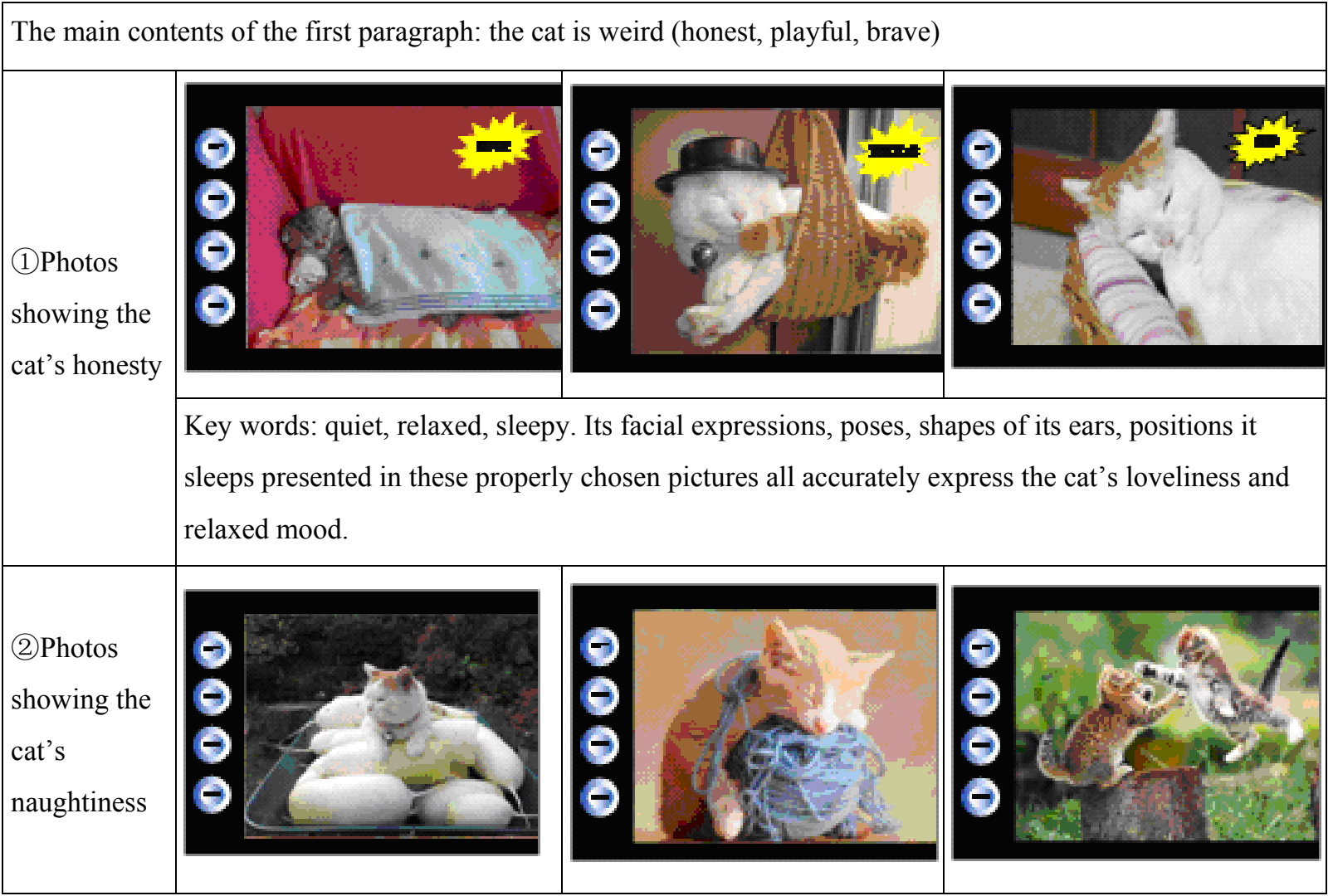




\begin{tabular}{|l|l|l|}
\hline & $\begin{array}{l}\text { The cat is very naughty. It will lie on the radish or sleep in a ball of yarn or jump up to the stumps } \\
\text { frolic. All these indicate its inclination of playing. } \\
\text { (3)Photos } \\
\text { showing the } \\
\text { cat's bravery }\end{array}$ \\
\cline { 2 - 4 } & When the cat catches a mouse, it is conscientious, concentrated, quick, and smart. The above \\
& pictures can achieve the aim of highlighting a cat's performance of catching its pray.
\end{tabular}

Pictures are more suitable for the display of static information or instant display of dynamic information. As for the display of other information that entails dynamic processes. Videos are suggested to be adopted, as is shown in the table:

Chart 2. Video Applications of curriculum informatization

\begin{tabular}{l}
\hline Videos showing the cat's tenderness and naughtiness \\
The gentle nature of the cat: how does a cat "rub" people? The video (45") shows the \\
poses, facial expressions and acts of a cat rubbing its owner and the loving response \\
of the owner. The video shows interactions between the cat and its owner, and every \\
detail of the whole process of the cat rubbing the owner. \\
The fourth paragraph mainly describes the kitten's loveliness and naughtiness. The \\
video named The Kitten in a Shoe (1'21') shows a cute kitten tries hard to get out of \\
a shoe and rolls around on a sofa. The video matches perfectly with the description of \\
the article of Mr. Lao She and the auxiliary teaching effect is remarkable.
\end{tabular}

Summary: A comparative analysis (data from classroom observation and statistics)

Chart 3. Curriculum informatization before and after comparison

\begin{tabular}{|c|c|c|c|c|c|}
\hline \multicolumn{6}{|c|}{ A teacher two times Tutoring } \\
\hline \multirow{2}{*}{ 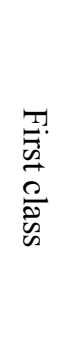 } & $\begin{array}{c}\text { Teaching } \\
\text { object }\end{array}$ & $\begin{array}{l}\text { XIMEN Elementary School } \\
\text { fourth grade (1) Class } \\
\text { Number of students: } 100\end{array}$ & \multirow{2}{*}{ 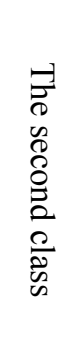 } & $\begin{array}{c}\text { Teaching } \\
\text { object }\end{array}$ & $\begin{array}{l}\text { XIMEN Elementary School fourth } \\
\text { grade (1) Class } \\
\text { Number of students: } 100\end{array}$ \\
\hline & $\begin{array}{l}\text { Teaching } \\
\text { methods }\end{array}$ & Oral teaching & & $\begin{array}{l}\text { Teaching } \\
\text { methods }\end{array}$ & $\begin{array}{l}\text { Watch enjoy } \\
\text { Self-experience }\end{array}$ \\
\hline
\end{tabular}




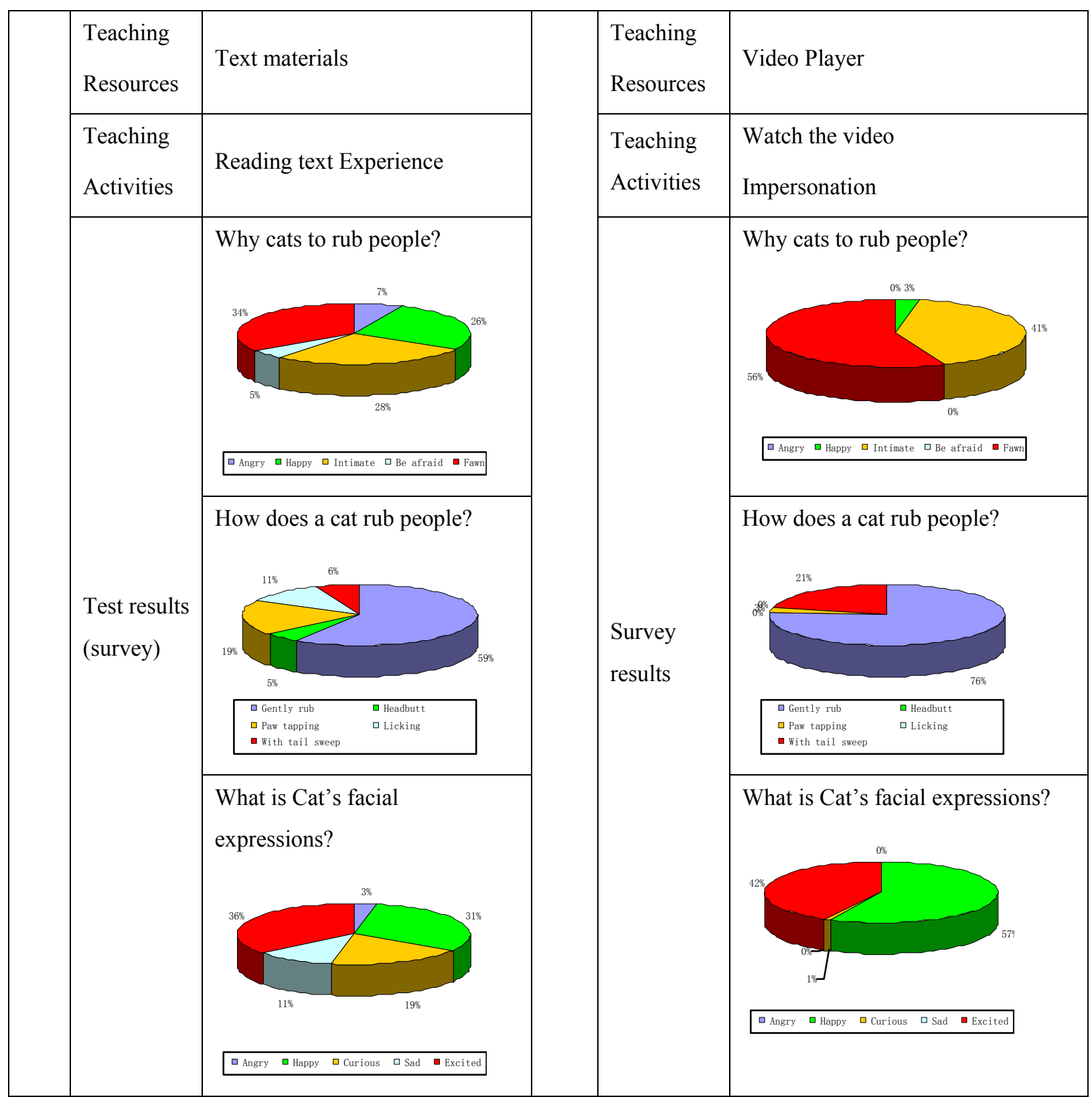

Analysis of test results: The first question, "Why do cats rub people?" Answer accurately rate the previous $62 \%$ (intimate28\% + fawn36\%) raised to $97 \%$; The second question, "How does a cat rub people?" Answer the previous accuratly rate of $72 \%$ (gently rub59\% + with tail sweep $6 \%$ ) raised to $97 \%$; The third question "What is Cat's facial expressions?" answered accurately rate before $67 \%$ (happy $31 \%+36 \%$ ) improved to $99 \%$. It can be seen, the scientific information instructional design for enhance students' understanding is very significant.

\subsection{The Course Design Process}

The design of primary Chinese curriculum should focus on entertainment and perception. On the basis of edutainment, the design should emphasize the integration of entertaining elements and recreational activities so that students can play an important part in participating in class activities and employing curriculum resources in a relaxed and delightful mood. Therefore, the design should take into account the specific course contents and allow for recreational activities. For example, to strengthen students reading ability, the author chose the article Cat in the Chinese textbook of the fourth grade and asked students to read together, read silently, listen to and read to each other, and read after the teacher. To enhance the students' speaking ability, the author asked the students to speak out what they saw in a picture and comment on the video they watched as well as on their classmates' answers. To help them practice writing, the author asked the students to make up sentences and 
describe what the cat was like in their minds. To make the students understand the text more easily, the author asked the students to perform the acts of a cat rubbing people, cat walk, and cat scream and so on. The whole process went well and the students were very eager to participate in each stage of the class in an atmosphere of knowledge, joy, and laughter.

\subsection{The Design and Implementation of Course Focuses and Difficult Points}

The design of course focuses highlights emphasizing and understanding, while the design of difficult points focuses on explanations. Each course or text has a focus or difficult points. If teachers only entertain students but neglect the essence of the course, it will not be worth the candle. Therefore, it is also necessary to strengthen the understanding of the course focuses, such as important glossaries, sentences or paragraphs. It is also necessary to elaborate on difficult points so that students can understand them more accurately.

\subsection{The Design and Implementation of Course Expansion}

The design and implementation of course expansion attach more stress to improving and promoting oneself. While learning Chinese as a tool for communication, pupils are required to be able to read, make up words and sentences, and write. They are also demanded to know more about the cultural connotation of Chinese literacy. Different course contents will expand in different directions and to different extents. For example, Mr. Lao She expressed his love for cats in his article Cat in the textbook of the fourth grade of primary school. However, teachers' conclusion should not just stop here but should extend to a broader and higher level. For instance, teachers can inspire students to think that human beings love cats throughout the history, cats make contributions to mankind by catching mice, man should learn from cats, and people should help stray cats, and so forth.

\section{Effects Assessment of the Informatization of Primary School Chinese Curriculum from the Perspective of Edutainment}

How to evaluate teaching effectiveness? Based on "edutainment" of information technology teaching, we have to consider in improving students' achievement, at the same time give more consideration to students' learning experience. For the teaching effectiveness of assessment, we can not just stay in the sense of self, there are some data to support my point of view.

Chart 4. The result of curriculum informatization before and after test comparison

Comparing the results of two tests

\begin{tabular}{|c|c|c|}
\hline Test object & \multicolumn{2}{|c|}{ XIMEN Elementary School fourth grade (1) Class, Number of students: 100} \\
\hline Test methods & \multicolumn{2}{|l|}{ Questionnaire Quiz } \\
\hline \multirow[t]{2}{*}{ Test question } & $\begin{array}{l}\text { Knowledge test } \\
\text { (there are } 16 \text { questions) }\end{array}$ & $\begin{array}{l}\text { Emotional experience test } \\
\text { (Learning emotional experience ) }\end{array}$ \\
\hline & $\begin{array}{l}\text { A. Can students read new words(10 } \\
\text { questions)? } \\
\text { B. Can students use key word to } \\
\text { make sentence? (10 questions); } \\
\text { C. Can students understand real } \\
\text { meaning of context? (Students } \\
\text { describe the main idea of context); }\end{array}$ & $\begin{array}{l}\text { D. Easy }(5,4,3,2,1) \text { tension } \\
\text { E. Exciting }(5,4,3,2,1) \text { fatigue } \\
\text { F. Interestingly }(5,4,3,2,1) \text { dull } \\
\text { G. Active }(5,4,3,2,1) \text { Passive } \\
\text { H. Understandable }(5,4,3,2,1) \text { incomprehensible } \\
\text { I. Inspired }(5,4,3,2,1) \text { receive } \\
\text { J. Free }(5,4,3,2,1) \text { Pressure }\end{array}$ \\
\hline
\end{tabular}




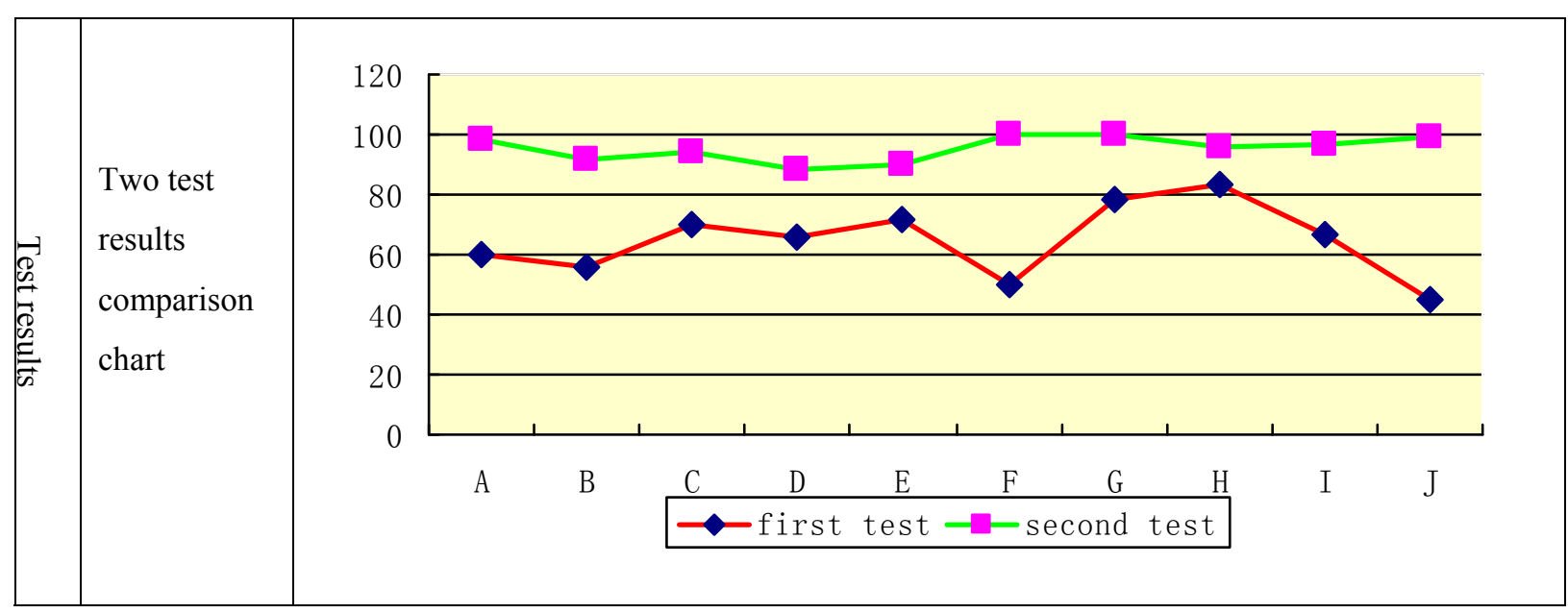

By comparison chart above test results, we can see that the entertainment element in the integration of teaching, make full use of information technology, it makes teaching effectiveness has been significantly improved and reflects the effectiveness of curriculum informatization. We must also understand that information teaching effectiveness evaluation is very complex, edutainment is also a long-term impact on students, it also need to go through more practice and experiment to study.

\section{References}

Li, H. K. (2008). Information Technology Teaching Within the Perspective of "Edutainment". Journal of Hubei University (Philosophy and Social Science), 2.

Trial Implementation. (2001). The Outline of Basic Education Curriculum Reform. China Education Newspaper, P. 2 .

Yang, J. J. (2008). New Courses and Three-dimensional Goal: Understanding and Implementation. Educational Research, 9, 40-46.

Xie, K. (2005). Under the Vision of Educational Information, Course Information Technology. China Educational Technology, 5, 35-38.

Hao, D. Y. (2006). The New Curriculum Reform: The Crux of and Beyond. Educational Research, 5, $25-29$.

Sun, H. G., \& Xie, K. (2009). Course Informatization System Theory. China Distance Education, 7, 61-64.

\section{Copyrights}

Copyright for this article is retained by the author(s), with first publication rights granted to the journal.

This is an open-access article distributed under the terms and conditions of the Creative Commons Attribution license (http://creativecommons.org/licenses/by/3.0/). 